\title{
Distribution of Antibiotic Susceptibility Profiles of Bacteria Frequently Isolated in Blood Cultures by Years
}

\section{öz}

Kan dolaşımı infeksiyonları yüksek mortalite ve morbiditeyle seyreden infeksiyonlardır. Bu çalışmanın amacı kan kültürlerinde üreyen mikroorganizmaları ve antibiyotik duyarlılıklarını analiz ederek ampirik tedavi seçeneklerini belirlemektir. Ocak 2015-Aralık 2018 tarihleri arasında yatan hastalara ait 666 kan kültür sonucu retrospektif olarak incelenmiştir. Kan kültürü örnekleri BACTEC FX 40 (Becton Dickinson, ABD) otomatik kan kültürü sisteminde inkübe edilmiștir. Bakteri tanımlanması ve antibiyotik duyarlılıkları Phoenix ${ }^{T M} 100$ (Becton Dickinson, ABD) otomatize sistemle belirlenmiştir. İolatların çoğunluğu yoğun bakım ünitelerinden elde edilmiştir (\% 70). En sık izole edilen patojenler Escherichia coli (\% 21) Enterococcus faecalis (\% 17) ve Staphylococcus aureus (\% 16)'tur. S.aureus izolatlarında metisilin direnci 2015-2018 yılları arasında sırasıyla \% 38, \% 15, \% 29, \% 45 iken, vankomisin direnci gözlenmemistir. Enterococcus faecium suşlarında ise \% 12 oranında vankomisin direnci bulunmuştur. E.faecalis suşlarında 2015-2017 yılları arasında vankomisin direnci gözlenmezken, 2018 yılında üç izolatta direnç saptanmıştır. Genislemis spektrumlu beta-laktamaz (GSBL) oranı E.coli için 2015-2018 yılları arasında \% 32 , \% 77, \% 57 ve \% 46 iken, K.pneumoniae'da sırasıyla \% 53, \% 81, \% 84, \% 77 bulunmuştur. E.coli suşlarında karbapenem direnci oldukça düşük (\% 0-11) iken, K.pneumoniae suşlarında bu oran \% 13-\% 38 arasında saptanmıștır. A.baumannii suşları ise tüm antibiyotiklere yüksek oranda dirençlidir (\% 73-\% 100). Pseudomonas aeruginosa suşlarını incelediğimizde tüm antibiyotiklere daha düşük direnç (\% 0-27) gözlenmiş, özellikle amikasin ve meropenem oldukça etkin bulunmustur.

Sonuç olarak, K.pneumoniae suşlarında giderek artan karbapenem direnci ve enterokok suşlarındaki vankomisin direnci ciddi sorundur. Bu nedenle, her hastane kendi antibiyotik direnç oranlarını takip etmeli ve buna göre ampirik tedavi seçeneklerini gözden geçirmelidir.

Anahtar kelimeler: Ampirik tedavi, antibiyotik direnci, bakteri, kan kültürü, karbapenem direnci

\section{ABSTRACT}

Bloodstream infections are associated with high mortality and morbidity. This study aimed to determine the empirical treatment options by analyzing the microorganisms and antibiotic susceptibility in blood cultures. Between January 2015 and December 2018, 666 blood culture results of inpatients were analyzed retrospectively. Blood culture samples were incubated in the BACTEC FX 40 (Becton Dickinson, USA) automated blood culture system. Bacterial identification and antibiotic susceptibilities were determined by the Phoenix ${ }^{\mathrm{TM}} 100$ automated system (Becton Dickinson, USA). The majority of strains were obtained from intensive care units (70\%). The most common pathogens were Escherichia coli (21\%) Enterococcus faecalis (17\%) and Staphylococcus aureus (16\%). Methicillin resistance was 38\%, $15 \%, 29 \%$ and $45 \%$ in S.aureus isolates between 2015-2018, respectively, whereas vancomycin resistance was not detected. Vancomycin resistance was found in $12 \%$ of Enterococcus faecium. While vancomycin resistance was not observed in E.faecalis between 2015-2017, it was detected in three isolates in 2018. The rate of extendedspectrum beta-lactamase (ESBL) for E.coli was $32 \%, 77 \%, 57 \%$ and $46 \%$ between 2015 and 2018, while it was $53 \%, 81 \%, 84 \%, 77 \%$ in K.pneumoniae, respectively. While carbapenem resistance was very low (0-11\%) in E.coli strains, this rate was $13-38 \%$ in K.pneumoniae strains. A. baumannii strains were highly resistant to all antibiotics (73 \% -100\%).

Pseudomonas aeruginosa strains showed lower resistance to all antibiotics (0-27\%), particulary amikacin and meropenem.

In conclusion, carbapenem resistance in K.pneumoniae strains and vancomycin resistance in enterococci are serious problems. Therefore, each hospital should monitor their antibiotic resistance rates and review the empirical treatment options accordingly.

Keywords: Antibiotic resistance, bacteria, blood culture, carbapenem resistance, empirical therapy

(c) Telif hakkı Antibiyotik ve Kemoterapi (ANKEM) Derneği'ne aittir. Logos Tıp Yayıncılık tarafindan yayınlanmaktadır. Bu dergide yayınlanan bütün makaleler Creative Commons Atff-Gayri Ticari 4.0 Uluslararası Lisansı ile lisanslanmıştır.
Alındığı tarih: 14.09.2019

Kabul tarihi: 08.11.2019

Yayın tarihi: 30.12 .2019

Şerife Satılmış Karabük Üniversitesi Eğitim Araştırma Hastanesi, Mikrobiyoloji Laboratuvarı, Karabük - Türkiye serifesatilmis89@gmail.com ORCID: 0000-0001-5310-3933

N. Aşgın 0000-0001-9739-5675 Karabük Üniversitesi EAH

Mikrobiyoloji Laboratuvarı Karabük Üniversitesi Tıp Fakültesi, Tıbbi Mikrobiyoloji Anabilim Dalı Karabük - Türkiye 


\section{Giriş}

Kan dolaşımı infeksiyonları, uygun antimikrobiyal tedavinin uygulanması geciktiğinde yüksek oranda mortalite ve morbiditeyle sonuçlanabilen ağır infeksiyonlardır. Ampirik anti enfeksiyöz tedaviler klinik ve epidemiyolojik verilere dayanarak seçilmekte ve kan kültürü alındıktan hemen sonra başlanmaktadır ${ }^{(4,14)}$. Bakteriyemi tanısında kan kültürü "altın standart" olarak kabul edilir. Ancak örneğin alınma zamanından itibaren mikrobiyoloji laboratuvarlarının Gram boyama sonuçlarını verme süresi ortalama bir gün, mikroorganizmaları tanımlanması iki gün, antimikrobiyal duyarlılık sonuçlarını bildirmesi ise ortalama üç günü bulmaktadır ${ }^{(21)}$. Literatürde bazı çalışmalar ampirik tedavilerin genellikle uygun olmadığını, bu durumun da artmış mortalite ve morbiditenin yanısıra, hastanede yatış süresinin uzamasına ve maliyetlerin de yükselmesine neden olduğunu ortaya koymuştur ${ }^{(5,15,17)}$. Bu nedenle her hastane kan kültürlerinde etken mikroorganizma ve antibiyotik duyarlılıklarında oluşan değişiklikleri belirlemeli ve ampirik tedavide bunları göz önünde bulundurmalıdır. Çünkü kan kültüründen izole edilen mikroorganizmaların dağılımı ve antibiyotik duyarlılık oranları hastanenin büyüklüğü, bulunduğu bölge ve klinisyenlerin uyguladığı rutin tedavi protokollerine göre farklılıklar göstermektedir ${ }^{(4)}$. Bu çalışmada amacımız Karabük Üniversitesi Eğitim Araştırma Hastanesi Mikrobiyoloji Laboratuvarı'na gelen kan kültürlerinde en sık üreyen mikroorganizmalar ve antibiyotik direnç oranlarının yıllara göre dağılımı belirlemek ve bu sayede uygun ampirik tedavinin seçimine katkıda bulunmaktır.

\section{GEREÇ VE YÖNTEM}

Çalışmamızda Karabük Üniversitesi Eğitim Araştırma Hastanesi Mikrobiyoloji Laboratuvarı́na Ocak 2015 ve Aralık 2018 tarihleri arasında kabul edilen kan kültür sonuçları retrospektif olarak değerlendirilmiştir. Çalışmaya kan kültüründe en sık izole edilen etken bakteriler (Escherichia coli,
Klebsiella pneumoniae, Pseudomonas aeruginosa, Acinetobacter baumannii complex, Staphylococcus aureus, Enterococcus faecalis, Enterococcus faecium) alınmış olup her hasta için ilk gönderilen kan kültür örneğindeki üreyen mikroorganizma dahil edilmiştir. Tekrarlayan üremeler ve kan kültürlerinde sıklıkla izole edilmesine rağmen çoğunlukla cilt florası bakterileri ile kontamine olarak değerlendirilen koagülaz negatif stafilokoklar çalışma dışı bırakıımıştır ${ }^{(4)}$. Çalışmaya dahil edilen bakterilerin etken olup olmadığının değerlendirilmesinde ise üreme saptanan kan kültürü sayısı, hastane bilgisayar sisteminden elde edilen hastalara ait klinik bilgiler ve laboratuvar sonuçları (beyaz küre sayısı, prokalsitonin ve CRP düzeyi) dikkate alınmıştır $^{(1)}$. Kan kültürleri BACTEC FX 40 (Becton Dickinson, $A B D$ ) otomatik kan kültürü sisteminde yedi gün inkübe edilmiştir. Üreme sinyali veren örneklerden Gram boyama hazırlanmış ve bu örnekler \% 5 koyun kanlı agar, Eosin metilen Blue (EMB) agar ve çukulata agara ekilerek etüvde $37^{\circ} \mathrm{C}^{\prime}$ de $24-48$ saat inkübe edilmiştir. Besiyerlerinde üreme gözlenen mikroorganizmaların tanımlanmasında konvansiyonel yöntemler ve Phoenix ${ }^{\mathrm{TM}}$ (Becton Diagnostics, $\mathrm{ABD}$ ) tam otomatize sistemi kullanılmıştır. Etken mikroorganizmaların antibiyotik duyarlılıkları 2018 yılına kadar Clinical and Laboratory Standards Institute kriterleri( ${ }^{(3)}$, 2018 yilında European Committee on Antimicrobial Susceptibility Testing kriterleri(7) doğrultusunda KirbyBauer disk difüzyon yöntemi, E-test (bioMérieux, France) ve Phoenix tam otomatize sistemi ile belirlenmiştir. Enterobacterales takımında karbapenem direnci, Enterococcus spp. izolatlarında ise vankomisin ve teikoplanin direnci gradient test yöntemi ile E- test stripleri kullanılarak doğrulanmıştır. Kalite kontrol suşları olarak S.aureus ATCC 29213, E.coli ATCC 25922, P.aeruginosa ATCC 27853 kullanıımıştır.

Antibiyotik dirençleri arasında yıllara göre anlamlı bir farkın olup olmadığı SPSS 22 programında ki-kare testi ile değerlendirilmiş, $p$ değeri $<0.05$ ise istatistiksel olarak anlamlı kabul edilmiştir. Çalışma için Karabük Üniversitesi Tıp Fakültesi Girişimsel Olmayan Klinik Araştırmalar Etik Kurulu'ndan 77192459-050.99-E.41309 sayılı etik kurul onayı alınmıştır. 


\section{BULGULAR}

Çalışmaya toplam 666 kan kültürü sonucu dahil edilmiştir. Bu örneklerin yıllara ve kliniklere göre dağılımına baktığımızda en çok üreme 2018 yılında görülmüş olup (217/666) bütün yıllardaki bakteriler en sık yoğun bakım üniteleri daha sonra sırasıyla dahili servisler ve cerrahi servislerdeki hastaların kan kültürlerinden izole edilmiştir (Tablo 1).

Kan kültüründe üreyen bakterilerin yıllara göre dağııımı Tablo 2'de sunulmuştur. Toplamda en sık izole edilen bakteri E.coli olarak bulunmuştur.

E.coli'deki genişlemiş spektrumlu beta laktamaz (GSBL) üretimi 2015-2018 yılları arasında sırasıyla $\% 32, \% 77, \% 57, \% 46$ olup yıllara göre GSBL üretimi arasında anlamlı farklılık gözlenmiştir $(p=0.004)$.
K.pneumoniae için ise GSBL üretimi sırasıyla \% 53, $\% 81, \% 84, \% 77$ olarak bulunmuştur ve yıllara göre dağııımında anlamlı farklılık saptanmamıştır $(p=0.15)$. Gram pozitif koklardan S.aureus suşlarında metisiline direnç oranı sırasıyla \% 38, \% 15, \% 29, \% 45'dir ve yıllar arasında direnç oranında anlamlı bir fark gözlenmemiştir $(p=0.13)$. Enterokoklarda ise vankomisin direnci sırasıyla $\% 4, \% 8, \% 3$ ve $\% 10$ olarak bulunmuş ve anlamlı bir farklılık saptanmamıştır ( $p=0.44)$.

Gram negatif çomak ve Gram pozitif koklarda en sık kullanılan antibiyotiklere direnç oranları ise Tablo 3, 4 ve 5'te gösterilmiştir. E.coli de siprofloksasin, gentamisin ve amikasin direnç oranının yıllara göre dağılımında anlamlı farklılıklar gözlenmiş $(p=0.009$, $p=0.007, p=0.03), 2016$ yılında direnç oranı en yüksek olarak belirlenmiştir (Tablo 3). E.faecium suşlarında

Tablo 1. Kan kültüründe bakteri üreyen hastaların kliniklere ve yıllara göre dağııımı [n (\%)].

\begin{tabular}{|c|c|c|c|c|c|}
\hline & 2015 & 2016 & 2017 & 2018 & Toplam \\
\hline Yoğun Bakım Üniteleri & $112(73)$ & $111(70)$ & $99(72)$ & $142(65)$ & $464(70)$ \\
\hline Dahili Klinikler & 38 (25) & $35(22)$ & $32(23)$ & 67 (31) & $172(26)$ \\
\hline Cerrahi Klinikler & $3(2)$ & $12(8)$ & $7(5)$ & $8(4)$ & $30(4)$ \\
\hline Toplam & $153(100)$ & $158(100)$ & $138(100)$ & $217(100)$ & 666 (100) \\
\hline
\end{tabular}

Tablo 2. Yıllara göre hastalarda kan kültüründen izole edilen bakteri türlerinin sayıları ve oranları [n (\%)].

\begin{tabular}{|c|c|c|c|c|c|}
\hline & 2015 & 2016 & 2017 & 2018 & Toplam \\
\hline E.coli & $34(22)$ & 30 (19) & $28(20)$ & $50(23)$ & $142(21.3)$ \\
\hline K.pneumoniae & $15(10)$ & $16(10)$ & $25(18)$ & $26(12)$ & $82(12.3)$ \\
\hline P.aeruginosa & $11(7)$ & $15(10)$ & $12(9)$ & $10(5)$ & $48(7.2)$ \\
\hline A.baumannii & $11(7)$ & 30 (19) & $21(15)$ & 41 (19) & $103(15.4)$ \\
\hline S.aureus & $26(17)$ & $20(13)$ & 21 (15) & $40(18)$ & $107(16)$ \\
\hline E.faecalis & $35(23)$ & $29(18)$ & $18(13)$ & $28(13)$ & $110(16.5)$ \\
\hline E.faecium & $21(14)$ & $18(11)$ & $13(10)$ & $22(10)$ & 74 (11.1) \\
\hline Toplam & $153(100)$ & $158(100)$ & $138(100)$ & $217(100)$ & $666(100)$ \\
\hline
\end{tabular}

Tablo 3. E.coli ve K.pneumoniae izolatlarının antibiyotik direnç durumunun yıllara göre dağılımı [n (\%)].

\begin{tabular}{|c|c|c|c|c|c|c|c|c|}
\hline & \multicolumn{4}{|c|}{ E.coli } & \multicolumn{4}{|c|}{ K.pneumoniae } \\
\hline & 2015 (34) & $2016(30)$ & $2017(28)$ & $2018(50)$ & 2015 (15) & $2016(16)$ & $2017(25)$ & $2018(26)$ \\
\hline Piperasilin-tazobaktam & $6(18)$ & $12(40)$ & $6(21)$ & $11(22)$ & $8(53)$ & $7(44)$ & $13(52)$ & $16(61)$ \\
\hline Siprofloksasin & $15(44)$ & $18(60)$ & $14(50)$ & $12(24)$ & $4(27)$ & $7(44)$ & $14(56)$ & $12(46)$ \\
\hline Gentamisin & $12(35)$ & $11(37)$ & $4(14)$ & $5(10)$ & $6(40)$ & $7(44)$ & $10(40)$ & $11(42)$ \\
\hline Amikasin & 4 (12) & $10(33)$ & $4(14)$ & $5(10)$ & $3(20)$ & $2(13)$ & $6(24)$ & $8(31)$ \\
\hline Sefepim & $12(35)$ & $23(77)$ & $13(46)$ & $19(38)$ & $9(60)$ & $12(75)$ & $20(80)$ & $19(73)$ \\
\hline Seftriakson & $12(35)$ & $23(77)$ & $13(46)$ & $22(44)$ & $9(60)$ & $13(81)$ & $21(84)$ & $19(73)$ \\
\hline Seftazidim & $12(35)$ & $24(80)$ & $11(39)$ & $20(40)$ & 7 (47) & $12(75)$ & $19(76)$ & $20(77)$ \\
\hline İmipenem & $2(6)$ & - & $1(4)$ & $1(2)$ & $1(7)$ & 2 (13) & $6(24)$ & 9 (35) \\
\hline Meropenem & $2(6)$ & - & $1(4)$ & $1(2)$ & $1(7)$ & $2(13)$ & $6(24)$ & $9(35)$ \\
\hline Ertapenem & $2(6)$ & - & $3(11)$ & $3(6)$ & $2(13)$ & $2(13)$ & $9(36)$ & $10(38)$ \\
\hline
\end{tabular}


Tablo 4. P.aeruginosa ve A.baumannii izolatlarının antibiyotik direnç oranlarının yıllara göre dağııımı [n (\%)].

\begin{tabular}{|c|c|c|c|c|c|c|c|c|}
\hline & \multicolumn{4}{|c|}{ P.aeruginosa } & \multicolumn{4}{|c|}{ A.baumannii } \\
\hline & $2015(11)$ & $2016(15)$ & $2017(12)$ & $2018(10)$ & $2015(11)$ & $2016(30)$ & $2017(21)$ & $2018(41)$ \\
\hline Ampisilin-sulbaktam & - & - & - & - & $10(91)$ & $30(100)$ & $21(100)$ & 39 (95) \\
\hline Trimetoprim-sülfametoksazol & - & - & - & - & $8(73)$ & $24(80)$ & $21(100)$ & $38(93)$ \\
\hline Piperasilin-tazobaktam & $3(27)$ & $3(20)$ & $3(25)$ & $1(10)$ & $10(91)$ & $30(100)$ & $21(100)$ & $39(95)$ \\
\hline Siprofloksasin & $4(36)$ & $3(20)$ & $1(8)$ & $1(10)$ & $11(100)$ & $29(97)$ & $21(100)$ & $37(90)$ \\
\hline Gentamisin & $2(18)$ & $3(20)$ & $1(8)$ & $1(10)$ & $11(100)$ & $28(93)$ & 20 (95) & $38(93)$ \\
\hline Amikasin & $1(9)$ & $2(13)$ & $1(8)$ & $0(0)$ & $11(100)$ & $28(93)$ & $20(95)$ & $34(83)$ \\
\hline Sefepim & $2(18)$ & $3(20)$ & $3(25)$ & $1(10)$ & & & & \\
\hline Seftazidim & $2(18)$ & $4(27)$ & $3(25)$ & $1(10)$ & $11(100)$ & $30(100)$ & $21(100)$ & $40(98)$ \\
\hline İmipenem & $3(27)$ & $2(13)$ & $1(8)$ & $1(10)$ & $10(91)$ & $29(97)$ & $21(100)$ & $36(88)$ \\
\hline Meropenem & $3(27)$ & $1(7)$ & $0(0)$ & $1(10)$ & $10(91)$ & $29(97)$ & $21(100)$ & $36(88)$ \\
\hline
\end{tabular}

Tablo 5. S.aureus ve E.faecium/faecalis izolatlarının antibiyotik direnç oranlarının yıllara göre dağılımı [n (\%)].

\begin{tabular}{|c|c|c|c|c|c|c|c|c|}
\hline & \multicolumn{4}{|c|}{ S.aureus } & \multicolumn{4}{|c|}{ E.faecium/faecalis } \\
\hline & $2015(26)$ & $2016(20)$ & $2017(21)$ & $2018(40)$ & $2015(21 / 35)$ & $2016(18 / 29)$ & $2017(13 / 18)$ & $2018(22 / 28)$ \\
\hline Ampisilin & - & - & - & - & $18(86) / 2(6)$ & $17(94) / 2(7)$ & $12(92) / 2(11)$ & $19(86) / 1(4)$ \\
\hline Eritromisin & $8(31)$ & $4(20)$ & $8(38)$ & $12(30)$ & - & - & - & - \\
\hline Klindamisin & $3(12)$ & $3(15)$ & $2(10)$ & $3(8)$ & - & - & - & - \\
\hline Trimetoprim-sülfametoksazol & $4(15)$ & $1(5)$ & $3(14)$ & $5(13)$ & - & - & - & - \\
\hline Gentamisin & $11(42)$ & $2(10)$ & $1(5)$ & $8(20)$ & - & - & - & - \\
\hline Sefoksitin & $10(38)$ & $3(15)$ & $6(29)$ & $18(45)$ & - & - & - & - \\
\hline Siprofloksasin & $4(15)$ & $4(20)$ & $3(14)$ & $8(20)$ & $11(52) / 12(33)$ & $17(94) / 15(52)$ & $11(85) / 13(72)$ & $19(86) / 22(79)$ \\
\hline Vankomisin & $0(0)$ & $0(0)$ & $0(0)$ & $0(0)$ & $2(10) / 0(0)$ & $4(22) / 0(0)$ & $1(8) / 0(0)$ & $2(9) / 3(11)$ \\
\hline Teikoplanin & $0(0)$ & $0(0)$ & $0(0)$ & $0(0)$ & $2(10) / 0(0)$ & $4(22) / 0(0)$ & $1(8) / 0(0)$ & $2(9) / 1(4)$ \\
\hline Yüksek düzey gentamisin & - & - & - & - & $4(19) / 19(53)$ & $4(22) / 16(55)$ & $7(54) / 11(61)$ & $16(73) / 13(46)$ \\
\hline D test* & $2(8)$ & $1(5)$ & $5(24)$ & $7(18)$ & - & - & - & - \\
\hline
\end{tabular}

*: Indüklenebilir klindamisin direnci

ise yüksek düzey gentamisin direnci 2015'den 2018'e kadar artış göstermiş olup yıllar arasında anlamlı farklılık saptanmıştır ( $p=0.001$ ) (Tablo 5). Diğer suşlarda ve antibiyotik dirençlerinde yıllara göre dağılımında anlamlı farklılıklar gözlenmemiştir ( $p>0.05)$.

\section{TARTIŞMA}

Çalışmamızda dört yıllık süre içinde kan kültüründe en sık izole edilen bakteriler ve antibiyotik direnç durumları değerlendirilmiştir. Bu bakterilerin izole edildiği hastalar incelendiğinde büyük çoğunluğunun (\% 70) yoğun bakım ünitesinde yatmakta olduğu gözlemlenmiştir. Yoğun bakım ünitesini dahili servisler takip etmekte olup cerrahi servislerde çok düşük oranda üreme olmuştur. Bu durum cerrahi servislerde hastaların daha hızlı taburcu edilmesiyle ve durumu stabil olmayan hastaların tedavisine yoğun bakım ünitelerinde devam edilmesiyle açıklanabilir. Kılınç ve ark. ${ }^{(11)}$ da yaptıkları çalışmada kan kültüründe üreyen Gram negatif bakterilerin önemli bir kısmının (E.coli izolatlarının \% 38'i, K.pneumoniae izolatlarının \% 62 si P.aureuginosa izolatlarının \% 63'ü, Acinetobacter spp. izolatlarının \% 86'sı) yoğun bakım hastalarından izole edildiğini bildirmişlerdir. Yakın zamanlı yayınlanan başka bir çalışmada ise etken mikroorganizmalar en çok dahili servislerde yatan hastalarda (\% 47.5) üremiş, bu durum yoğun bakım ünitelerindeki hızlı hasta sirkülasyonuna ve hastaların tedavilerinin servislerde devam ettirilmesine bağlanmıştır(4).

Çalışmamızda kan kültürü örneklerinden en sık izole edilen bakteri E.coli (\% 21.3) olup bunu E.faecalis (\% 16.5) ve S.aureus (\% 16) takip etmektedir. Benzer şekilde, Khan ve ark. ${ }^{(10)}$ da \% 21.5 oranıyla en sık E.coli izole ettiklerini bildirmişlerdir. Halk Sağlığı Genel Müdürlüğü tarafından yürütülmekte olan 
“Ulusal Antimikrobiyal Direnç Sürveyans Sistemi'nin (UAMDSS) dahil olduğu Dünya Sağlık Örgütü Orta Asya ve Doğu Avrupa Antimikrobiyal Direnç Sürveyans Ağı'nın (CAESAR) 2018 raporuna göre 2017 yılında Türkiye'deki kan ve beyin omurilik sıvısı izolatlarında da en sık izole edilen bakteri \% 24 oranıyla E.coli'dir (2). Bunun yanısıra etken bakteri dağılımları coğrafi bölgelere ve hastanelere göre değişmektedir. Coşkun'un ${ }^{(4)}$ 2016-2017 yılları arasında Tokat'ta yaptığı çalışmada \% 17.2 oranıyla E.coli, \% 16.7 oranıyla $A$. baumannii en çok üreyen mikroorganizmalar olarak göze çarparken, Sevim ve ark. ${ }^{(16)}$ İzmir de yaptığı çalışmalarında S.aureus oranını \% 24 olarak tespit etmiştir. Şahin ve ark. ${ }^{(19)}$ ise Düzce'de yaptıkları çalışmada en çok üreyen mikroorganizmaların koagülaz negatif stafilokoklar (\% 42) ve S.aureus (\% 21) olduğunu bildirmişlerdir. Kan kültüründe üreyen etken mikroorganizmaların tespitinin yanısıra antibiyotik duyarlıık sonuçlarının da klinisyenlere en kısa zamanda bildirilmesi gerekmektedir. Çünkü antibiyotik direnci dünya çapında büyük bir halk sağ lığı sorunudur(8).

Çalışmamızda kan kültürlerinden izole edilen mikroorganizmalarda hem dar spektrumlu, hem de son basamak antibiyotiklere karşı direnç gözlenmiş olup direnç oranları yıldan yıla değişim göstermiştir. Gram pozitif bakterilerden S.aureus izolatlarında \% 35 oranında metisilin direnci tespit edilmiş ve 2015 ve 2018 yılları arasında bu oranlar sırasıyla $\% 38, \% 15, \% 29, \% 45$ olarak bulunmuştur. Yıllara göre metisilin direncinde anlamlı farklılık saptanmasa da 2018 yılında metisiline dirençli S.aureus (MRSA) oranının oldukça yükseldiği göze çarpmaktadır. CAESAR surveyans raporuna göre 2017 yılında Türkiye'deki kan ve beyin omurilik sIvısı (BOS) izolatlarında MRSA oranı bizim çalışmamıza yakın oranlarda \% 36 olarak bulunmuştur ${ }^{(2)}$. Türkiye'de yapılan diğer çalışmalarda Nazik ve ark. ${ }^{(13)}$ 2014-2016 yılları arasında kan kültüründe izole edilen S.aureus suşlarında MRSA oranını sırasıyla \% 33, \% 45 ve \% 57 olarak bulmuşlar ve oranların dramatik bir şekilde arttığını belirtmişlerdir. Şafak ve ark. ${ }^{(18)}$ kan kültürlerinde 2010-2015 yılları arasında MRSA oranını ortalama \% 62.6 bulurken, Küçükateş ve ark. ${ }^{(12)}$ yoğun bakım ünitelerinde yaptıkları çalışmalarında MRSA'yı \% 60 gibi yüksek oranlarda bulmuştur. Avrupa'daki MRSA oranlarına baktığımızda ise European Antimicrobial Resistance Surveillance Network (EARS-Net) raporlarına göre 2014 yılında bu oran \% 19.6 iken, 2017 yılında \% 16.9'a gerilemiştir(25). Bu oran ülkemize göre oldukça düşüktür.

Çalışmamızda en sık izole edilen gram pozitif bakteriler olan Enterokok izolatlarını irdelediğimizde ise E.faecium için glikopeptid direnci 2015, 2017 ve 2018 yıllarında \% 5-10 arasındayken, 2016 yılında \% 22 ile en yüksek oranda görülmüştür. UAMDSS 2016 raporunda Türkiye genelinde E.faecium için vankomisin direncinin \% 16 olduğu belirtilmiştir(23). Çalışmamızda E.faecalis izolatlarında ise 2015-2017 yılları arasında glikopeptid direncine rastlanmazken, 2018 yılında üç suşta vankomisin direnci, bir suşta ise teikoplanin direncinin gözlendiği dikkat çekmektedir. Yüksek düzey gentamisin direnci E.faecalis suşlarında \% 45-61 oranlarında olup, E.faecium izolatlarında yıldan yıla \% 19'lardan \% 73'lere doğru dramatik bir artış sergilemiş ve yıllar arasındaki bu fark anlamlı bulunmuştur $(p=0.001)$. UAMDSS verilerine göre Türkiye'deki E.faecium izolatlarındaki yüksek düzey gentamisin direnci 2014-2016 yılları arasında sırasıyla $\% 43, \%$ 69, \% 61.7; E.faecalis suşlarında ise \% 22, $\% 54, \% 57.2$ oranındadır. CAESAR 2018 raporuna göre ise 2017 yılında Türkiye'deki kan ve BOS örneklerinden izole edilen E.faecium suşlarında yüksek düzey gentamisin direnci \% 52 olup çalışmamıza oldukça yakın bir değerde bulunmuştur ${ }^{(2)}$.

Enterik Gram negatif bakterilerde ise antibiyotik direncine neden olan önemli mekanizmalardan GSBL ve karbapenemaz üretimi beta laktam antibiyotiklerin ana direnç mekanizmasıdır. Bu çalışmada GSBL üretimi E.coli için 2015-2018 yılları arasında sırasıyla $\% 32, \% 77, \% 57$ ve \% 46 iken, K.pneumoniae için 2015 yılında \% 53 olup diğer yıllarda ise \% 80-85 gibi yüksek düzeylere çıkmıştır. UAMDSS 2016 raporuna göre Türkiye'de E.coli izolatlarında GSBL üretimi $\% 47.8$, K.pneumoniae için ise \% 58' dir $^{(23)}$. Literatürde ise Coşkun ${ }^{(4)}$ GSBL üretimini E.coli ve K.pneumoniae için sırasıyla \% 46.7-\% 35.6 olarak bildirmiştir. Şirin ve ark. ${ }^{(20)}$ da E.coli için \% 35.4, K.pneumoniae için \% 37.9 
oranında GSBL üretimi olduğunu belirtmiştir. Bizim çalışmamızda GSBL üretiminin bu çalışmalara göre oldukça yüksek olduğu dikkat çekmektedir. Özellikle E.coli suşlarında 2016 yılında GSBL üretimi diğer yıllara göre yüksek oranda bulunmuş ve yıllara göre anlamlı farklılık saptanmıştır $(p=0.004)$. Ayrıca E.coli'de siprofloksasin, gentamisin ve amikasin direnç oranlarının da 2016 yılında en yüksek olduğu görülmektedir. Bu durum GSBL üreten kökenlerde çoklu ilaca direnç oranının yüksek olmasıyla ilişkilendirilebilir. Çalışmamızda karbapenem direnci K.pneumoniae izolatlarında 2015-2018 yılları arasında giderek yükselen oranlarıyla (sırasıyla \% 13, \% 13, $\% 36, \% 38$ ) dikkat çekmektedir. UAMDSS raporuna göre ise 2015 yılında K.pneumoniae için karbapenem direnci \% 30 iken, 2016 yılında \% 40.1 olup çalışmamıza göre yüksek oranda bulunmuş, 2017 yılında ise \% 38 ile çalışmamıza benzer oranda bulunmuştur ${ }^{(22-24)}$. Literatüre baktığımızda yakın zamanlı bir çalışmada karbapenem direnci E.coli için $\%$ 2, K.pneumoniae için ise \% 30 oranında bulunmuştur ${ }^{(4)}$. Şafak ve ark. ${ }^{(18)}$ ise Klebsiella spp.'de 2014 yılında \% 15.2, 2015 yılında ise \% 41.1 suşta karbapenem direnci olduğunu belirtmiştir. Karbapenem direnci nonfermenter bakterilerde de gözlenmektedir. Çalışmamızda A.baumannii izolatlarında karbapenem direnci oldukça yüksek olup \% 88 ile \% 100 arasında bulunmuştur. A.baumannii suşlarında çalışılan tüm antibiyotiklere literatürdeki diğer çalışmalarda olduğu gibi yüksek oranda direnç (\% 73-\% 100) gözlenmiştir. Kolistin için gradient test çalışılmış olmasına rağmen EUCAST artık sadece sıvı mikrodilüsyon yöntemini önerdiğinden kolistin direnci irdelenememiştir. Bu durum çalışmanın kısıtılığını oluşturmaktadır. Diğer nonfermenter patojen olan P.aeruginosa izolatlarında ise karbapenem direnci \% 0-27 arasında değişmektedir. Ülkemizdeki çalışmalarda P.aeruginosa'da karbapenem direncini Er ve ark. ${ }^{(6)} \%$ 41.9, Coşkun ${ }^{(4)}$ \% 24.3, Kılınç ve ark. ${ }^{(11)} \%$ 17.1, Gür ve ark. ${ }^{(9)} \% 38.8$ olarak bulmuşlardır. Çalışmamızda P.aeruginosa izolatlarının amikasin ve meropeneme karşı oldukça duyarlı olduğu gözlenmiştir. Gür ve ark. ${ }^{(9)}$ da çalışmalarında P.aeruginosa izolatlarının çoğunluğu- nun amikasine duyarlı olmasının tedavide umut vaad ettiğini belirtmiştir.

Sonuç olarak çalışmamızı diğer çalışmalardan ayıran durum en sık izole edilen bakterilerin ve antibiyotik duyarlılık profillerinin yıllara göre çıkarılmış olması, böylece dört yıllık süreçte artan direnç oranlarının ve izolatların en duyarlı olduğu antibiyotiklerin belirlenmesidir. Enterokoklar ve stafilokoklarda glikopeptit ve metisilin direnci 2018 yılında artış gösterirken, K.pneumoniae de karbapenem direnci 2016-2018 yılında oldukça yüksek oranlarda (\% 80-85) bulunmuştur. Bu çalışma sayesinde hastanemizde kullanılacak ampirik antibiyotik tedavi protokollerine katkıda bulunulmuştur. Ancak giderek artan antibiyotik direnci nedeniyle mutlaka infeksiyon kontrol önlemleri geliştirilmeli ve etkin antibiyotik kontrol politikaları uygulanmalıdır.

Çıkar Çatışması: Yazarlar tarafından herhangi bir çıkar çatışması bildirilmemiştir.

Conflict of Interest: No conflict of interest was declared by the authors.

\section{KAYNAKLAR}

1. Balıkçı A, Belas Z, Topkaya A. Kan kültürü pozitifliği: etken ya da kontaminasyon mu? Mikrobiyol Bul. 2013;47(1):135-40. https://doi.org/10.5578/mb.4181

2. Central Asian and Eastern European Surveillance of Antimicrobial Resistance CAESAR Annual Report (2018). https://hsgm.saglik.gov.tr/tr/uamdss.

3. CLSI. Clinical and Laboratory Standards Institute. Performance Standards for Antimicrobial Susceptibility Testing; M100. 27th edition, (2017).

4. Coşkun USŞ. Kan kültürlerinde üreyen mikroorganizmalar ve antibiyotik duyarlılıkları. ANKEM Derg. 2018;32(2):45-52.

5. Diamantis S, Rioux C, Bonnal C, et al. Suitability of initial antibiotic therapy for the treatment of bloodstream infections and the potential role of antibiotic management teams in improving it. Eur J Clin Microbiol Infect Dis. 2012;31(7):1667-71. https://doi.org/10.1007/s10096-011-1491-8. PMid: 22134774

6. Er H, Aşık G, Yoldaş Ö, Demir C, Keşli R. Kan 
kültürlerinde izole edilerek tanımlanan mikroorganizmaların ve antibiyotik direnç oranlarının belirlenmesi. Türk Mikrobiyol Cem Derg. 2015;45(1):48-54.

https://doi.org/10.5222/TMCD.2015.048

7. European Committee on Antimicrobial Susceptibility Testing. Breakpoint tables for interpretation of MICs and zone diameters. Version 8.1, (2018). http:// www.eucast.org

8. Gandra S, Mojica N, Klein EY, et al. Trends in antibiotic resistance among major bacterial pathogens isolated from blood cultures tested at a large private laboratory network in India, 2008-2014. Int J Infect Dis. 2016; 50(1):75-82.

https://doi.org/10.1016/j.ijid.2016.08.002

PMid: 27522002

9. Gür H, Hazırolan G. Kan kültürlerinden izole edilen nonfermentatif gram negatif bakterilerin dağılımının ve antibiyotik duyarlılık profillerinin belirlenmesi. ANKEM Derg. 2019;33(2):49-57.

https://doi.org/10.5222/ankem.2019.1915

10. Khan FY, Elshafie SS, Almaslamani M, Abu-Khattab $M$, El Hiday $A H$, Errayes $M$, Almaslamani $E$. Epidemiology of bacteraemia in Hamad general hospital, Qatar: a one year hospital-based study. Travel Med Infect Dis. 2010; 8(6):377-87.

https://doi.org/10.1016/j.tmaid.2010.10.004

PMid: 21074495

11. Kılınç Ç, Güçkan R, Kahveci M, Kayhan Y, Pirhan Y, Özalp T. Kan kültürlerinde üreyen gram negatif izolatların dağılımı ve antibiyotik direnç profilleri. Int J Basic Clin Med. 2015;3(3):125-30.

12. Küçükateş $E$, Gültekin N. Yoğun bakım ünitelerinde yatan hastaların kan kültürlerinden izole edilen mikroorganizmalar ve antimikrobiyal duyarlılıkları. Med Bull Haseki. 2016;54(2):97-102.

https://doi.org/10.4274/haseki.2872

13. NazikS, Cingöz E, Şahin AR, Güler S. Kan Kültürlerinden izole edilen Staphylococcus aureus suşlarında metisilin direncinin yıllara göre değişimi. Kocaeli Med J. 2018;7(1):32-6.

https://doi.org/10.5505/ktd.2018.94824

14. Opota O, Croxatto A, Prod'hom G, Greub G. Blood culture-based diagnosis of bacteremia: state of the art. Clin Microbiol Infect. 2015;21(4):313-22.

https://doi.org/10.1016/j.cmi.2015.01.003

PMid: 25753137

15. Paul M, Shani V, Muchtar E, Kariv G, Robenshtok E, Leibovici L. Systematic review and meta-analysis of the efficacy of appropriate empiric antibiotic therapy for sepsis. Antimicrob Agents Chemother. 2010; 54(11):4851-63.

https://doi.org/10.1128/AAC.00627-10

PMid: 20733044

16. Sevim S, Öztürk Ş, Coşkuner A, Özgenç O, Avcı M. Bactec kan kültür sistemi ile izole edilen mikroorganizmaların değerlendirilmesi. İnfek Derg. 2007;21(3):135-40.

17. Shorr AF, Micek ST, Welch EC, Doherty JA, Reichley $\mathrm{RM}$, Kollef $\mathrm{MH}$. Inappropriate antibiotic therapy in Gram-negative sepsis increases hospital length of stay. Crit Care Med. 2011;39(1):46-51. https://doi.org/10.1097/CCM.0b013e3181fa41a7

18. Şafak B, Kılınç O. 2010-2015 yılları arasında kan kültürlerinde üreyen mikroorganizmalar ve antibiyotik duyarlılıkları. Klimik Derg. 2016;29(2):60-4.

19. Şahin I, Çalışkan E, Öztürk E, et al. Kan kültürlerinden izole edilen mikroorganizmaların dağılımı ve antimikrobiyal duyarlılıkları. Düzce Tıp Derg. 2013;15(2):11-4.

20. Şirin $M C$, Ağuş N, Yılmaz $N$ ve ark. Yoğun bakım ünitelerinde yatan hastaların kan kültürlerinden izole edilen mikroorganizmalar ve antibiyotik duyarlılıkları. Turk Hij Den Biyol Derg. 2017;74(3):269-78. https://doi.org/10.5505/TurkHijyen.2017.94899

21. Tabak YP, Vankeepuram L, Ye G, Jeffers K, Gupta V, Murray PR (2018) Blood Culture Turnaround Time in US Acute Care Hospitals and Implications for Laboratory Process Optimization. J Clin Microbiol. 2018;56(12):e00500-18. https://doi.org/10.1128/JCM.00500-18 PMid: 30135230

22. T.C. Sağlık Bakanlığı Türkiye Halk Sağlığı Kurumu Mikrobiyoloji Referans Laboratuvarları Daire Başkanlığı. Ulusal Hastane Enfeksiyonları Sürveyans Ağı Özet Raporu 2014-2015. Ankara. (2015)

23. T.C. Sağlık Bakanlığı Türkiye Halk Sağlığı Kurumu Mikrobiyoloji Referans Laboratuvarları Daire Başkanlığı. Ulusal Hastane Enfeksiyonları Sürveyans Ağı Özet Raporu 2016. Ankara. (2016).

24. T.C. Sağlık Bakanlığı Türkiye Halk Sağlığı Kurumu Mikrobiyoloji Referans Laboratuvarları Daire Başkanlığı. Ulusal Hastane Enfeksiyonları Sürveyans Ağı Özet Raporu 2017. Ankara. (2017).

25. The European Antimicrobial Resistance Surveillance Network (EARS-Net) (2017). https://ecdc.europa.eu/ en/publications-data/surveillance-antimicrobialresistance-europe-2017. 